\title{
For a public policy of surveillance of suicidal behavior
}

\author{
Pela política pública de atenção ao comportamento suicida \\ Por la política pública de atención al comportamiento suicida
}

\author{
João Fernando Marcolan' \\ ' Universidade Federal de São Paulo, Paulista School of Nursing. São Paulo, Brazil.
}

How to cite this article:

Marcolan JF. For a public policy of surveillance of suicidal behavior. Rev Bras Enferm [Internet]. 2018;71(Suppl 5):2343-7.

[Thematic Issue: Mental health] DOI: http://dx.doi.org/10.1590/0034-7167-2018-0256

Submission: 04-04-2017 Approval: 05-21-2018

\begin{abstract}
The object is to reflect on the need for effective implementation of a surveillance program of suicidal behavior and of the causal and intervening factors of suicide, as well as to training and qualification of health professionals about this topic, and the profile of the individual with suicidal behavior. Suicidal behavior is public health serious, global problem and it should be faced in a consensual way by public administrators, professionals and population. Suicide is a real, current catastrophe and a kind of death that can be avoided.
\end{abstract}

Descriptors: Suicide; Public Health Surveillance; Public Health Policy; Mental Health; Psychiatric Nursing.

\section{RESUMO}

Refletir sobre a necessidade de implantação efetiva de um programa de vigilância ao comportamento suicida e sobre os fatores causais e intervenientes do suicídio, além da formação e qualificação dos profissionais da área da saúde quanto a este tema e o perfil do indivíduo com comportamento suicida. O comportamento suicida é um grave problema mundial de saúde pública e deve ser enfrentado de modo consensual por gestores, profissionais e população. O suicídio é uma verdadeira catástrofe hodierna e um tipo de morte que pode ser evitada.

Descritores: Suicídio; Vigilância em Saúde Pública; Políticas Públicas de Saúde; Saúde Mental; Enfermagem Psiquiátrica.

\section{RESUMEN}

Reflejar sobre la necesidad de implantación efectiva de un programa de vigilancia al comportamiento suicida y sobre los factores causales e intervinientes del suicidio, además de la formación y de la cualificación de los profesionales del área de la salud cuanto a este tema y el perfil del individuo con el comportamiento suicida. El comportamiento suicida es un grave problema mundial de salud pública y debe ser enfrentado de modo consensual por los gestores, los profesionales y por la población. El suicidio es una verdadera catástrofe hodierna y un tipo de muerte que puede ser evitada.

Descriptores: Suicidio; Vigilancia en Salud Pública; Políticas Públicas de Salud; Salud Mental; Enfermería Psiquiátrica. 
The suicidal behavior consists of ideation, planning and the suicide attempt. According to data from the World Health Organization (WHO), a person kills him/herself every 40 seconds, and suicide attempts can be from four to 40 times more frequent depending on the specific geographical region; the number of suicides in the world has grown $60 \%$ in recent years ${ }^{(1)}$. There was an increase in suicidal behavior in adolescents and young adults, but the rates among adults and seniors remained high ${ }^{(1)}$. A real current catastrophe, suicide is a kind of death that can be avoided if there is an early discovery of such behavior and if appropriate interventions are implanted.

The suicidal behavior has a multifactorial etiology $y^{(1)}$ and cannot be seen and treated only in organic/biological contexts, which narrows the possibilities of interventions and leads to their failure and the repetition or chronification of this behavior. The organic, psychological, sociocultural and environmental aspects are mixed and act decisively to determine the suicidal behavior. Commonly, suicide does not occur because of a single cause or a single stressor, but in a cumulative way; several risk factors offer the individual a greater vulnerability to suicide behavior. Therefore, the suicidal behavior requires understanding and a multidimensional approach.

In literature, it is easy to find mental disorders as the main factor of suicidal behavior, emphasizing the medical treatment when there are other factors to notice and intervene, such as psychological (traumas, conflicts, personality formation, emotional abandonment, abuses and other kinds of violence) and sociocultural factors (unemployment, loneliness, lifestyle). The human being is at a decisive moment, in a capitalist model that stimulates as much as possible the consumerist, individualistic way of being, and the achievement of success at any cost, even if ephemeral, as in Facebook and other social networks, where the personal exhibition is inflated in search of recognition, "likes" that reveal the unbridled search for affection and belonging.

Despite the support provided by technological advances in the digital age, there is also the misuse of these technologies, bringing serious damage, such as the detachment of people regarding the affective aspect, replacing face-to-face relations by distant, impersonal, diffuse, propagandized connection, without noticing the nonverbal expressed, "liking" what most people "like", trying to belong without real belonging, being only in an artificial world. We treated some cases, and others, widely known, were young people who attempted suicide because they did not get the number of "likes" expected.

The need for quick, effective resolutions is also generated; just look at how fast we behave in major urban centers (walking, eating, talking, everything very quickly, a fast way of living); we want quick solutions, we do not know how to live with frustrations and we seek pleasure, domain of hedonism, we cannot have displeasure. We go back to the beginning of pleasure of our spring days in the oral phase, when instinct needs to be educated so it does not bend us to its tyranny.

To make matters worse, our educational system is horrible, families do not offer solidity of ethical, human principles, our social fabric was stretched to the point of almost breaking. It is a great load for a single human being and, thus, conditions appear leading us to not bear suffering and to think immediately that our death is the most plausible way out-a thought that repeats itself intensely in the daily routine of many individuals.

We still have the influence of the environment, increasingly degraded by all kinds of pollution (visual, aural, atmospheric); each day there is less drinking water for all, the absence of sun can influence our circadian rhythm and the regulatory mechanisms of the sleep-wake cycle (cortisol-melatonin) causing mood changes, sometimes leading to pathology (depressive disorder) that leads to suicidal behavior.

We need to revise our lifestyle and invest in the emotional life, as our values influence primarily our mental health and the search for a fatal way out to the suffering we do not want and cannot bear.

\section{SUICIDAL BEHAVIOR IN BRAZIL}

In Brazil, we do not have a surveillance program to suicidal behavior, or even reliable data on the subject. The underreporting of suicidal behavior in health systems is notorious, as it is possible to verify the masking of data in practice and in research. Urgent calls in emergency rooms, clearly related to suicidal intention, are still under diagnosis disguised as endogenous intoxication, injury by gun or cold weapons, and car accident. There are also those who try to or do kill themselves without having accessed a health equipment, and the survivors and family members hide the real cause for shame and moral judgment that surround suicide.

This is reflected on official data provided by the $\mathrm{WHO}$, which point out low suicide rate in the Brazilian population, 5.8 per 100,000 inhabitants, despite out eighth worldwide position regarding deaths ${ }^{(1)}$. This low rate is misleading, which is easily confirmed by professionals that assist individuals with suicidal behavior and survivors.

We noticed the increase in number of suicide attempts in the last three years because of the practice in our extension program, researches in Emergency Rooms, speeches of many mental health and emergency professionals, and data published by the Centro de Valorização da Vida, which points out the number of calls that doubled in 2017. Coincidentally, that period is attached to the serious ethical-political-economical crisis in the country, with a high unemployment rate, an intervening factor to suicidal behavior ${ }^{(1)}$.

We suffer calamitously the loss of several individuals that did not receive adequate assistance, and among them, some without even a correct record of their final act. Suicide is a taboo that still exists in the Brazilian society, and is full of prejudice rooted in moral-religious aspects and, especially, ignorance about it. Ignorance proliferates the obscurantism.

Forbidden subjects, such as euthanasia, orthothanasia, assisted suicide, suicide and sexuality, must be brought to light, with scientific discussions based on knowledge of areas such as Sociology, Philosophy, Anthropology, Psychology, Thanatology, Sexology, Suicidology etc., and not only biased by Medicine.

We must discuss, unveil and reveal knowledge to broaden the perspective of understanding and, consequently, adapting interventions linked to the several factors associated to suicidal behavior. It is not possible to keep consciously hiding something that occurs with increasing frequency, bringing immensurable suffering to the individual with suicidal behavior and those who live with him/her.

The WHO points out that for each individual that kills him/ herself, there are at least five or six people who will suffer with 
that outcome, and many others can be impacted, especially the families and people of the emotional circle (work and school colleagues, friends, religious community, groups of help and social action, among others) $)^{(1)}$.

The suffering of suicidal survivors - who are not only the individuals who attempted suicide, but also family members and other people of the emotional circle - becomes lonely and chronic, because, in most cases, such survivors do not seek help due to shame, fear and ignorance.

In our service to suicide survivors we noticed the exacerbated fear of suffering during medical treatment, due to the reports that are to be made, which activate the emotional memory, and the shame and fear of judgment. In general, this is the main reason for not seeking help.

Other fundamental point is the difficulty of treatment, because there is not enough mental health equipment to meet the demand of other cases in the same area, a situation that is aggravated for those with suicidal behavior. There is no reference service to specifically treat, supervise and train other health units. We also do not have professionals in appropriate number, nor qualified to assist the individual with suicidal behavior.

We noticed in our professional experience the harmful treatment commonly performed by doctors and nursing professionals to the individual who attempted suicide. Punishment, prejudice speeches, threats, moral judgment and verbal aggression were common attitudes seen in Emergency Rooms and other health units-unfortunately, also from mental health professionals, who should have a better understanding of the fact.

I still find myself in situations where the way to attempt suicide or the number of attempts become the care guideline: to determine if the individuals really wanted to die or just to "draw attention" to themselves, disregarding the suffering that led the person to such an act. It is very common, for example, the inadequacy of assistance to patients diagnosed with borderline personality disorder. Such facts reinforce the shame and fear the individuals with suicidal behavior have to seek care, especially when they are not in a life-threatening situation.

The Health Sciences programs, in general, do not have contents regarding suicidal behaviors in their curricula; the training is superficial, centered in psychopathologies, without a curriculum unit or subject specific to that approach and without specialized teachers. The topic is interdicted in undergraduate health programs, a reflection of the society that hides the suicidal individual, not allowing the theme to be openly discussed, and making hypocrisy their helm, because when somebody commits suicide, it is as if the act was a punch in society's stomach, pointing out what this society has done to the person. Suicide is the reflection, - as Durkheim ${ }^{(2)}$ studied deeply - of a society, pointing out how much destructive aggressiveness it has and the lack of solidarity and emotional bonds among individuals.

The formative institution is the ideological apparatus of the State in the Althusserian sense. We do not have training nor qualification of professionals that mediate a suicide attempt in progress. The professional often cannot identify the six characteristics that can be found in individuals with suicidal behavior, which are fundamental to manage the crisis situation.
Even though the fantasy of the suicidal with his/her own death can be seen as universal, to determine their suffering, there are specific fantasies, such as the mystical-religious-oriented ones (going to a better place, meeting loved ones who have died), ideologically-oriented (sacrifices for causes that can be political, racial, honor or for the country), revenge, power, guilt, atonement, among others ${ }^{(3)}$. There is also call for help, in which every suicidal expresses their will to stay alive to the individual who assists them, silently asking to be taken off that situation, showing with their act how desperate they are and how much they need to regain hope in order to emerge and breathe the new air that sustains life. On the other hand, with their act, the aggression is externalized, which is distilled against the environment, shocking, generating guilt, hurting those that are part of their life, and even if at the time of the attempt there is only an audience of strangers, there is also an attempt of shocking those close to them ${ }^{(4)}$. Those who witness a suicide carry the impressive memory and the emotions aroused, and, in general, these people need care for the suffering created.

The method used to attempt suicide, the place, the time and the presence of target people say a lot about who tries to kill themselves and who they are trying to reach with this act ${ }^{(5)}$. To commit suicide in the workplace, in a place visible to everyone, or with objects of their own job, in front of the chief's office, says a lot about how relationships were at work.

The individuals with suicidal behavior present ambivalence, as there is an internal conflict between the desire to die/kill themselves and to stay alive. We must work therapeutically to reinforce the desire to live ${ }^{(6)}$. The individual presents rigidity of thought, which is fixed regarding the suicide as the only alternative to their suffering, as the final solution. When other options are offered and different views and approaches to their problems and suffering are worked, the possibility of reinforcing the will to live is opened. At last, we have an impulse present in individuals with suicidal behavior, which often leads to the execution of the attempt and the death.

In undergraduate programs in nursing, including specialization programs, there is no content to qualify nurses to assist an individual with suicidal behavior. We still have a strong training bias focused on the labor market, which, in its hegemony, serves the economic logic and not the social context; therefore, this training is not interested in the suicidal behavior. In Nursing, the technical formation is valued, which does not prioritize the critical reflexive analysis, the citizenry, the social paradigm change, the commitment of the Unified Health System (SUS - Sistema Único de Saúde), the humanization, nor the integrality of assistance.

There are countries that treat suicidal behavior as a public health issue and invest in assistance to Suicidology as a field of knowledge, as a subject, with programs to train suicidologists - professionals skilled in this assistance, showing the backwardness of Brazil in this area.

Suicidal behavior in university students is a global phenomenon, especially those in health areas, and we come across news about it that do not last long in newspapers and on television media, as it is a topic of great social discomfort, which causes uneasiness. Scientific researches around the world show this fact, with an increase in suicidal behavior in university students of health areas, especially Medicine and Nursing ${ }^{(7-10)}$. 
In our midst, we still have little research about the topic, but some local studies give us clues of what can happen with nursing students in a national level. In 2008, we performed a study about suicidal behavior in nursing students of the university in which we operate, and we did it again after ten years; we are in the final stage for disclosure of the data. We observed the lack of humanization regarding students; we, who theoretically emphasize so much the humanization of assistance, do not do it with students, the future professionals to provide assistance.

The nursing students pointed out factors of formation that aggravated preexisting psychopathologic conditions or promoted the suffering that led to suicidal behavior. The excess of activities such as seminars, tests, final course papers, participation in researches and academic leagues, elective disciplines, rigid curriculum, aridity of green areas, which leads to the lack of free time for recreation and leisure, and lack of adequate number of hours to sleep and to be with close people. Such data can be found repeatedly in studies on the topic. The students also pointed out the inadequate interpersonal relation with the professors-with their lack of understanding of the needs and problems the student has -, the situations to which they were subjected and in which they felt humiliated, the pressure of internships, the coldness and detachment of professors, and the feeling of incapacity.

This generation was not prepared and does not have this culture, therefore, they will suffer and fall ill easily, and suicide is the way out, often seen as the one and only option. Such fact needs to be detected and understood, receiving attention from the trainers. From the first survey in 2008 to the current one, there was a sevenfold increase in suicidal behavior among students and a tenfold increase among those who attempted suicide.

We must rethink, as trainers, what this teaching is and how much of it should be reformulated, leaving the square format, democratizing relationships and allowing learning in a more harmonious and pleasurable way, because we should train caregivers, and not generate suffering that leads to suicidal behavior in students.

The health professional's training must be reviewed regarding the way of teaching, the content, the format of the program, the interdisciplinary training in search of transdisciplinarity, the humanization of teaching and assistance, the several teaching scenarios, the democratization of relationships, the solidarity instead of competition among the faculty and also between students, and the healthy work environment that does not favor the Burnout syndrome.

There are also research data on suicidal behavior in health professionals, specifically those of nursing, that point on a large scale to depressive symptoms as an aggravation due to work conditions, with suicidal behavior as a consequence of this suffering.

\section{FINAL CONSIDERATIONS}

The Swedish model of surveillance to suicidal behavior was chosen for countries of the European community and is referenced by the $\mathrm{WHO}$; Brazil has, on paper, guidelines that should consolidate a program of surveillance of suicide, however, there has been no initiative from public administrators to put them into practice.

In Brazil, health and education, increasingly commodified, are not priorities. There are political, ideological and economic barriers to the full development of SUS, with the reform of the mental health care model, which leaves much to be desired regarding the precepts of the 1st, 2nd and 3rd national mental health conferences. The topic "suicide" remains taboo and it is difficult to implement a program of surveillance of suicidal behavior. We need to start this discussion, by ethically and scientifically ventilating the issue with the population, in order to decrease the prejudice and the stigma attached to suicide, mainly to save lives.

It is necessary to invest in training, in specializing and qualifying health professionals, particularly mental health professionals; we need Suicidology programs, we have to train individuals of reference in the social context to act preventively. We must invest in the training of professionals to act on preventing suicidal behavior, performing early diagnoses and interventions, monitoring suicide risk, mediating situations of suicide attempt in loco, and postvention to survivors.

We have to expand health equipment to assist individuals who need it and those from their emotional circle. There must be surveillance to detect/monitor and collect reliable data about the problem to intervene appropriately. The national plan/program must prioritize actions focused on preventing suicidal behavior and promoting health, treating risk groups and vulnerable individuals, according to the epidemiological profile detected.

There is much to do, but it is necessary to take the first step, as we know that suicidal behavior is a serious global problem of public health. We must not close our eyes and ignore it, because it is in the daily life of the national scenario, remembering us that little is being done to face this problem.

A joint effort is necessary, led by the Ministry of Health and the Municipal Health Secretariats, by the training institutions and the media, in order to reverse this discouraging picture. Taking actions is urgent to avoid unnecessary deaths, terrible suffering to survivors, and economical losses, as our system is concerned about this, even though we have reserve army, given the immense mass of unemployed people. In a country where you cannot trust official statistics on suicide, profound changes are needed.

\section{REFERENCES}

1. World Health Organization-WHO. Preventing suicide: a global imperative. Geneva: WHO; 2014.

2. Durkheim E. O suicídio. São Paulo: Martin Claret; 2003.

3. Cassorla RMS. Do suicídio: estudos brasileiros. São Paulo: Papirus;1991.

4. Menninger K. Eros e tanatos: o homem contra si próprio. São Paulo: Ibrasa,1970. 
5. Marquetti FC. O suicídio como espetáculo na metrópole. São Paulo: Fap-Unifesp; 2011.

6. World Health Organization-WHO. Preventing suicide: a resource series. Geneva: WHO; 2000.

7. Alves TCTF. Depression and anxiety among medical students. Rev Med[Internet]. 2014[cited 2018 Mar 01];93(3):101-5. Available from: http://www.revistas.usp.br/revistadc/article/viewFile/103400/101872

8. Monteiro C, Freitas J, Ribeiro A. Stress in the Academic Daily: A Nursing Student View from the Federal University of Piauí - Brazil. Esc Anna Nery Rev Enferm[Internet]. 2007[cited 2018 Mar 01];11(1):66-72. Available from: http://www.scielo.br/pdf/ean/v11n1/v11n1a09.pdf

9. Silva CA, Pereira MLG, Bustamante C, Ferraz ACT, Baldassin S, Andrade AG, et al. Suicidal ideation among students enrolled in healthcare training programs: a cross-sectional study. Rev Bras Psiquiatr[Internet]. 2009[cited 2018 Mar 01];31(4). Available from: http://www.scielo.br/pdf/rbp/v31n4/aop0909.pdf

10. Melissa-Halikiopoulou C, Tsiga E, Khachatryan R, Papazisis G. Suicidality and depressive symptoms among nursing students in northern Greece. Health Sci J[Internet]. 2011[cited 2018 Mar 01];5(2):1-8. Available from: http://www.hsj.gr/medicine/suicidalityand-depressive-symptoms-among-nursing-students-in-northern-greece.pdf 